\title{
Analisis Kesalahan Siswa dalam Menyelesaikan Soal Cerita Materi Sistem Persamaan Linear Dua Variabel Ditinjau dari Taksonomi Solo pada Siswa
}

\author{
Seila Azmia ${ }^{1}$, Slamet Soro ${ }^{2}$ \\ 1,2 Pendidikan Matematika, Fakultas Keguruan dan Ilmu Pendidikan, Universitas Muhammadiyah Prof. Dr. HAMKA, \\ Jl. Tanah Merdeka No 20, Jakarta Timur, Indonesia \\ 91seilaazmia@gmail.com
}

\begin{abstract}
This study aims to identify and identify the location of the errors of junior high school students in solving thestory problems of the two-variable linear equation system (SPLDV) in terms of the SOLO taxonomy which has five different levels. This SOLO taxonomy classifies the level of response ability of students to problems. The five levels are prestructural (Prestructural), unistructural (Unistructural), multistructural (Multistructural), relational (Relational), and extended abstract (Extended Abstract). This type of research is descriptive qualitative. The research subjects were students of class VIII H at SMP Negeri 239 Jakarta for the academic year 2020/2021, totaling 35 students. Data collection techniques in this study used written tests, interviews, and observations. Technical analysis of data using trigulation which consists of data collection, data reduction and drawing conclusions. The results of the study based on the data that had been obtained showed that students' errors in terms of the SOLO taxonomy were at the multistructural level the most than at other levels. Student errors at the multistructural level are errors in counting, students have not been able to answer or have not been able to calculate the equations that have been obtained.
\end{abstract}

Keywords: Analysis, SOLO Taxonomy, SPLDV.

Abstrak
Penelitian ini bertujuan untuk mengetahui dan mengenalisis letak kesalahan siswa SMP dalam menyelesaikan soal cerita sistem persamaan linear dua variabel (SPLDV) ditinjau dari taksonomi SOLO yang memiliki lima tingkatan level yang berbeda. Taksonomi SOLO ini mengklasifikasikan tingkat kemampuan respon pada siswa terhadap masalah. Kelima tingkatan tersebut adalah prastruktural (Prestructural), unistruktural (Unistructural), multistruktural (Multistructural), relasional (Relational), dan abstrak diperluas (Extended Abstract). Jenis penelitian ini adalah deskriptif kualitatif. Subjek penelitian siswa kelas VIII H di SMP Negeri 239 Jakarta tahun ajaran 2020/2021 yang berjumlah 35 siswa. Teknik pengumpulan data pada penelitian ini menggunakan tes tertulis, wawncara, dan observasi. Teknis analisis data menggunakan trigulasi yang terdiri dari pengumpulan data, reduksi data dan penarikan kesimpulan. Hasil penelitian berdasarkan data yang sudah didapat menunjukkan bahwa kesalahan siswa ditinjau dari taksonomi SOLO terdapat pada level multistruktural yang paling banyak dari pada level lainnya. Kesalahan siswa pada level multistruktural adalah kesalahan dalam menghitung, siswa belum mampu menjawab atau belum mampu menghitug persamaan yang telah diperoleh.

Kata kunci: Analisis, Taksonomi SOLO, SPLDV

Copyright (c) 2021 Seila Azmia, Slamet Soro

$\square$ Corresponding author: Seila Azmia

Email Address: 91seilaazmia@gmail.com (Jl. Tanah Merdeka No 20, Jakarta Timur, Indonesia)

Received 09 June 2021, Accepted 05 July 2021, Published 19 July 2021

\section{PENDAHULUAN}

Pendidikan merupakan salah satu faktor yang menentukan kualitas sumber daya manusia. Pemerintah melakukan berbagai upaya untuk meningkatkan mutu pendidikan melalui penyempurnaan kurikulum. Penerapan kurikulum 2013 diharapkan bisa berjalan secara optimal untuk meningkatkan kualitas pendidikan terutama pada mata pelajaran matematika. Kita melihat peran pendidikan yang begitu penting, pendidikan sangat diperhatikan oleh pemerintah Indonesia. Tetapi saat ini pendidikan di Indonesia 
belum bisa dikatakan sukses, karena masih banyak kendala - kendala yang dialami pada setiap matapelajaran yang diajarkan, khususnya pada pelajaran matematika (Mudhiah \& Shodikin, 2019).

Matematika merupakan ilmu tentang struktur ilmu yang terorganisasikan dengan baik. Mata pelajaran matematika perlu diberikan kepada semua siswa dengan tujuan agar kemampuan berfikir siswa berkembang dan memberikan pengetahuan matematika kepada siswa. Tujuan belajar matematika adalah mendorong siswa untuk menjadi pemecah masalah berdasarkan proses berfikir yang kritis, logis dan rasional Menurut (Ilmiyah et al., 2018). Adapun tujuan pembelajaran matematika menurut Permendiknas Nomor 22 Tahun 2006 adalah siswa dapat: (1) Memahami konsep matematika, menjelaskan keterkaitan antar konsep dalam pemecahan masalah matematika. (2) Menggunakan penalaran pada pola dan sifat, melakukan pernyataan matematika, memanipulasi dalam membaut generalisasi, dan menyusun bukti. (3) Memecahkan masalah dengan memahami suatu masalah matematika, merancang model, menyelesaikan, dan menafsirkan solusi yang didapat. (4) Mengkomunikasikan gagasan dengan simbol, tabel, diagram untuk memperjelas keadaan atau masalah pada matematika. (5) Memiliki sikap menghargai kegunaan matematika dalam kehidupan, yaitu rasa ingin tahu, perhatian, dan minat dalam mempelajari matematika, serta sikap ulet dan percaya diri dalam pemecahan masalah matematis.

Pada pembelajaran matematika terdapat proses pemecahan masalah yang memainkan peranan penting di sekolah karena kemampuan pemecahan masalah ini merupakan kemampuan yang menuntut siswa untuk menyelesaikan suatu masalah matematika. Siswa yang mengalami kesulitan dalam pelajaran matematika, seringkali melakukan kesalahan dalam pengerjaan soal-soal matematika, hal ini terjadi karena siswa tidak paham pada materi atau tidak memahami konsep matematika. Ketidakcocokan metode dan sistem pengajaran yang diberikan oleh guru juga dapat menyebabkan siswa mengalami kesalahan dalam mengerjakan soal matematika (Goleman, 2019).

Melakukan kesalahan mengerjakan soal matematika merupakan suatu yang wajar. Mengingat bahwa matematika adalah mata pelajaran yang materinya saling terkait dan berhubungan dengan materi materi berikutnya. Kesalahan siswa dalam menyelesaikan soal-soal adalah kesalahan konsep, kesalahan operasi dan kesalahan ceroboh, dengan kesalahan dominan adalah kesalahan konsep (Farmasi, 2016). Kesulitan dalam memahami konsep - konsep soal adalah kesulitan yang sering dialami oleh siswa. Sejauh ini, materi yang sulit bagi sebagian siswa adalah aljabar. Aljabar ialah relasi dan bahasa simbol yang mempunyai kegunaan untuk menyelesaikan permasalahan yang berkaitan dengan kehidupan sehari-hari. Pokok bahasan SPLDV adalah salah satu materi Aljabar yang tepat digunakan dikarenakan banyak variasi pemecahan masalah tentang pokok bahasan SPLDV berbentuk soal cerita yang dapat diberikan kepada siswa. (Rosanggren et al., 2018).

Menurut (Islamiyah et al., 2018) Pokok bahasan Sistem Persamaan Linear Dua Variabel (SPLDV) adalah salah satu pokok bahasan pelajaran matematika di Sekolah. Dalam pokok bahasan seringkali siswa melakukan kesalahan dalam menyelesaikan soal yang berhubungan dengan pokok bahasan tersebut, sebagai contoh dalam membuat model matematika dari soal cerita dari pokok bahasan tersebut. Kesalahan kesalahan itu mungkin terjadi dikarenakan siswa kurang memahami materi atau bahkan tidak mengerti 
dengan materinya, kurangnya ketelitian siswa, maupun kurangnya pemahaman siswa dalam operasi aljabar menurut (Yuliana et al., 2019). Kesalahan-kesalahan yang diteliti pada penelitian ini adalah kesalahan menurut Taksonomi SOLO. Metode analisis Taksonomi SOLO ini adalah Teori yang dikenal dengan taksonomi Structure of the Observed Learning Outcome (SOLO). Taksonomi SOLO dapat mengklasifikasikan respon peserta didik dalam menyelesaikan soal matematika. Bahwa dengan menggunakan taksonomi SOLO merupakan alat evaluasi yang paling praktis untuk mengukur kualitas respon atau jawaban peserta didik terhadap suatu masalah berdasar pada kompleksitas pemahaman atau jawaban peserta didik terhadap masalah yang diberikan (Hardina \& Jamaan, 2018).

Taksonomi SOLO mengklasifikasikan tingkat kemampuan respon peserta didik terhadap masalah menjadi lima tingkat berbeda dan bersifat hirarkis. Kelima tingkatan tersebut adalah prastruktural (Prestructural), unistruktural (Unistructural), multistruktural (Multistructural), relasional (Relational), dan abstrak diperluas (Extended Abstract). Dari kelima level tersebut penjelasannya sebagai berikut: Pada level prastruktural, siswa memiliki sedikit informasi terhadap suatu pertanyaan, sehingga tidak memiliki makna apapun dalam memecahkan masalah. Pada level unistruktural siswa menggunakan sepenggal informasi yang jelas dan langsung dari soal untuk menyelesaikan masalah. Pada level multistruktural siswa menggunakan 2 penggal informasi atau lebih dari soal untuk menyelesaikan masalah dengan tepat tetapi tidak menggabungkan secara bersama-sama. Pada level relasional siswa dapat memadukan atau menghubungkan beberapa penggal informasi atau penyelesaian yang terpisah untuk menyelesaikan suatu masalah sehingga memiliki kesimpulan yang tepat. Pada level abstrak diperluas siswa mampu melakukan suatu hipotesis, dapat membuat generalisasi, dapat mengaitkan informasi, dan dapat menghasilkan prinsip yang umum dari suatu data dan dapat menerapkan pada situasi baru. (Arico \& Wahyudi, 2021).

Berdasarkan penjelasan tersebut peneliti bertujuan untuk mendeskripsikan dan menganalisa kemampuan pemecahan masalah siswa pada materi Sistem Persamaan Linear Dua Variabel (SPLDV) pada siswa kelas VIII H dalam bentuk soal cerita ditinjau dari tingkatan level Taksonomi SOLO di SMP Negeri 239 Jakarta. Dengan demikian, penulis melakukan penelitian dengan judul "Analisis Kesalahan Siswa Dalam Menyelesaikan Soal Cerita Materi Sistem Persamaan Linear Dua Variabel Ditinjau Dari Taksonomi SOLO”,

\section{METODE}

Jenis penelinian yang digunakan merupakan penelitian deskriptif dengan pendekatan kualitatif. Subjek penelitian ini adalah siswa kelas VIII H SMPN 239 Jakarta pada tahun ajaran 2020/2021 sebanyak 35 siswa. Pengumpulan data menggunakan triangulasi yang terdiri dari tes tertulis, wawancara dan observasi. Tes bertujuan untuk mengetahui apa saja kesalahan siswa, wawancara bertujuan untuk mengecek keabsahan data dan mengetahui penyebab kesalahan siswa, dan observasi bertujuan untuk melihat aktifitas dan kemampuan siswa dalam melakukan latihan - latihan yang diberikan oleh guru dikelas. Soal tes divalidasi oleh para ahli yaitu terdiri dari 6 butir soal pada materi sistem persamaan linear dua variabel. Teknis analisis data menggunakan pengumpulan data, reduksi data dan penarikan kesimpulan. Analisis 
dilakukan setelah mendapatkan deskripsi hasil dari pengumpulan data. Analisis tersebut untuk mengetahui kesalahan siswa dalam menyelesaikan soal cerita berdasarkan taksonomi SOLO.

\section{HASIL DAN DISKUSI}

Seluruh subjek penelitian menyelesaikan tes yang telah diberikan. Berdasarkan hasil tes terdapat kesalahan siswa dalam menyelesaikan soal cerita sistem persamaan linear dua variabel ditinjau dari taksonomi SOLO.

\section{Level Prastruktural}

Level prastruktural menunjukkan siswa belum dapat memahami masalah yang diberikan sehingga jawaban yang ditulis tidak memberi jawaban atas soal yang diberikan.

\section{Soal nomor 3}

Ibu Dewi membeli $3 \mathrm{~kg}$ beras dan $1 \mathrm{~kg}$ gula pasir dengan harga Rp. 39.000. pada took yang sama Bu Santi membeli $2 \mathrm{~kg}$ beras dan $3 \mathrm{~kg}$ gula dengan harga Rp. 54.000. apabila Bu Eti membeli $4 \mathrm{~kg}$ beras dan $2 \mathrm{~kg}$ gula, tentukan jumlah uang yang harus dibayar Bu Eti.

Jawaban siswa nomor 3

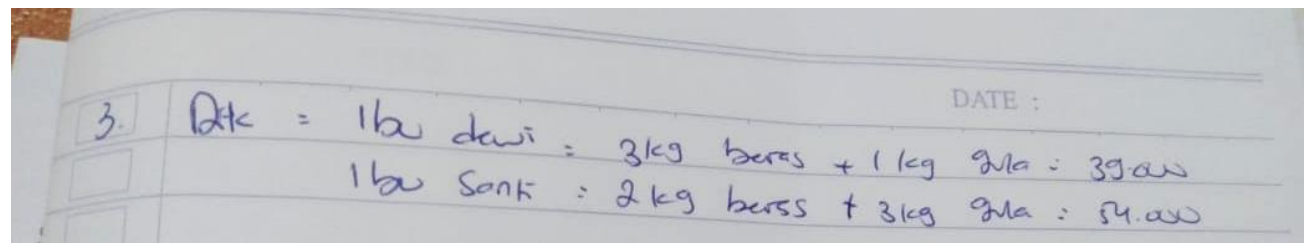

Gambar 1. Pekerjaan siswa AGA

Gambar 1 terlihat bahwa kesalahan siswa pada subjek AGA berdasarkan taksonomi SOLO adalah prastrustural karena siswa tidak mampu memisalkan informasi yang ada pada soal. Kesalahan tersebut karena siswa hanya menuliskan yang diketahui dalam soal saja tidak menjawab apa yang ditanyakan pada soal.

\section{Level Unistruktural}

Level unistruktural menunjukkan bahwa siswa hanya menggunakan sepenggal informasi yang jelas dan langsung menulis dari soal untuk menyelesaikan masalah.

Soal Nomor 2

Keliling sebuah kolam ikan dengan bentuk persegi panjang ABCD sama dengan $44 \mathrm{~cm}$. Jika lebarnya $6 \mathrm{~cm}$ lebih pendek dari panjangnya, carilah panjang dan lebar dari persegi panjang ABCD.

Jawaban Siswa Nomor 2

\begin{tabular}{c|c}
\hline $2 u(p+l)=k$ \\
$\square(p+p-6)=44$ \\
$2 v(2 p-6)=94$ \\
$\quad 2 p-12=44$ \\
$4 p=44+12$ \\
$4 p=56$ \\
$p=\frac{56}{4}=14 \mathrm{~cm}$ \\
$\square \quad$
\end{tabular}

Gambar 2. Pekerjaan siswa SFMK 
Gambar 2. menunjukkan kesalahan yang dilakukan oleh siswa SFMK pada level unistruktural. Karena siswa tidak menuliskan apa yang diketahui, ditanya pada soal, permisalan, dan siswa belum selesai dalam menjawab soal tersebut. subjek SFMK kurang memahami informasi apa yang ditanya pada soal.

\section{Level Multistruktural}

Pada level multistruktural menunjukkan siswa menggunakan 2 penggal informasi atau lebih dari soal untuk menyelesaikan masalah dengan tepat tetapi tdak menggabungkan secara bersama-sama.

\section{Soal nomor 4}

Luri dan Miska bekerja pada pabrik tas. Luri dapat meyelesaikan 3 buah tas setiap jam dan Miska dapat menyelesaikan 4 tas setiap jam. Jumlah jam kerja Luri dan Miska adalah 16 jam sehari dengan jumlah tas yang dibuat oleh keduanya adalah 55 tas. Jika jam kerja keduanya berbeda, Maka tentukan jam kerja mereka masing-masing.

\section{Jawaban Siswa Nomor 4}

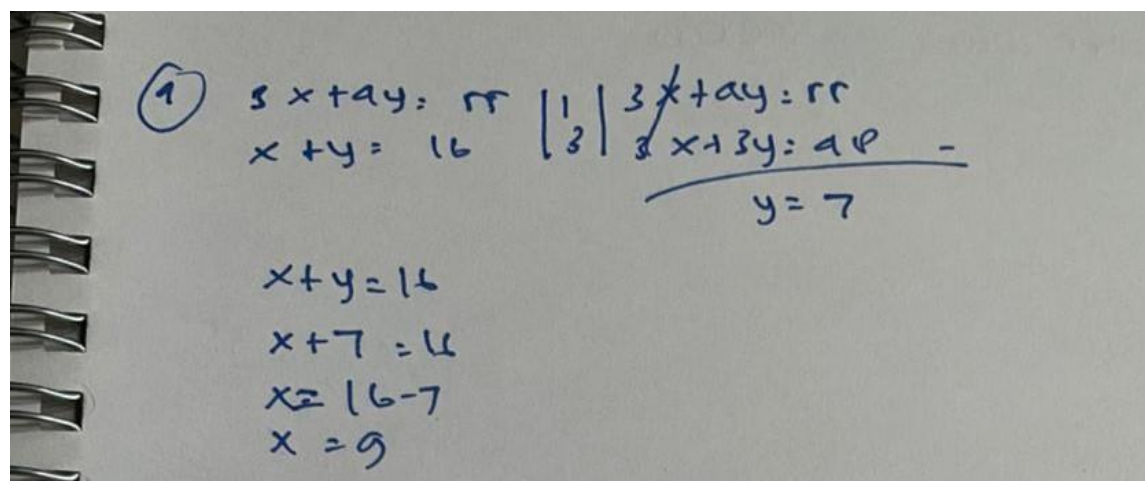

Gambar 3. Pekerjaan siswa DTS

Gambar 3. menunjukkan kesalahan yang dilakukan oleh siswa DTS yaitu pada level multistruktural. Karena kesalahan siswa DTS tidak menulis apa yang diketahui, ditanya pada soal, dan permisalan. Siswa sudah paham untuk langsung menyelesaikan dengan cara eliminasi dan substitusi. Tetapi tidak terdapat kesimpulan pada jawaban siswa.

\section{Level Relasional}

Pada level relasional siswa menunjukkan dapat memadukan atau menghubungkan dua informasi atau penyelesaian yang terpisah untuk menyelesaikan suatu masalah sehingga memiliki kesimpulan yang tepat. Pada gambar 4 berikut yang menunjukkan jawaban siswa nomor 1 menunjukkan bahwa siswa SPSM melakukan kesalahan pada level relasional. Kesalahan pada siswa tidak menuliskan apa yang diketahui dan yang ditanya pada soal. Untuk jawaban siswa sudah benar hanya kurang langkah-langkahnya.

\section{Soal Nomor 1}

Harga 2 pensil dan 3 penggaris Rp. 14.000 sedangkan harga 4 pensil dan 2 penggaris Rp. 16.000. Tentukan harga 3 pensil dan 2 penggaris. 
Jawaban Siswa Nomor 1

\begin{tabular}{|c|c|}
\hline$\square$ & jawab: \\
\hline$\square$ & misal : Pensil $=x$ \\
\hline$\square$ & Penggaris $=y$ \\
\hline$\square$ & a 20 \\
\hline$\square$ & $\Rightarrow 2 x+3 y=R p 14.000|\times 2| \psi x+6 y=R_{p} 28.000$ \\
\hline$\square$ & $4 x+2 y=R p 16.000|x| \mid 4 x+2 y=\operatorname{Rp} 16.000$ \\
\hline$\square$ & $4 y=12.000$ \\
\hline[] & $y=12.000=3.000$ \\
\hline[ & $4 \sqrt{4}$ \\
\hline 1$]$ & 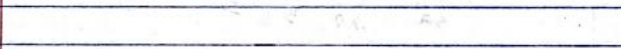 \\
\hline$\square$ & $\Rightarrow 2 x+3 y=14.000$ \\
\hline$C$ & $2 x+3(3.000)=14.000$ \\
\hline CD & $2 x+g .000=14.000$ \\
\hline$\square$ & $2 x=5.000$ \\
\hline$\square$ & $x=5.000=2.500$ \\
\hline$\square$ & 2 \\
\hline$\square$ & \\
\hline$\square$ & $\Rightarrow 3 x+2 y=\ldots$ \\
\hline$\square$ & $3(2.500)+2(3.000)=\ldots$ \\
\hline$\square$ & $7.500+6.000=R_{p} 13.500,-$ \\
\hline
\end{tabular}

Gambar 4. Pekerjaan siswa SPSM

\section{Level Abstrak Diperluas}

Level abstrak diperluas menunjukkan siswa mampu melakukan suatu hipotesis, dapat membuat generalisasi, dapat mengaitkan informasi, dan dapat menghasilkan prinsip yang umum dari suatu data dan dapat menerapkan pada situasi baru.

Pada hasil analisis tes yang telah dilakukan dan mengacu pada level ini, siswa yang termasuk dalam level ini mampu mendapat uang Rp. 26.000. jika terdapat 20 mobil dan 30 motor, tentukan banyak uang yang diperoleh tukang parkir.

Jawaban siswa nomor 6

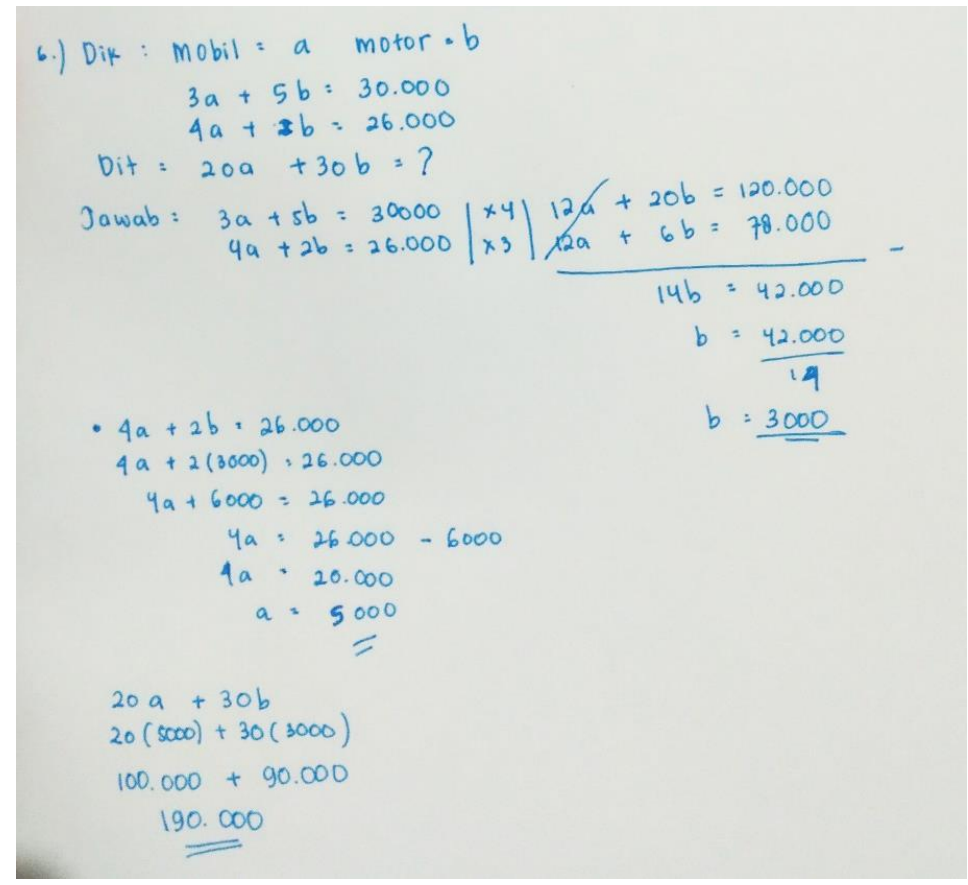

Gambar 5. Pekerjaan siswa DPS 
Berdasarkan gambar 5. terlihat bahwa subjek DPS mampu menyelesaikan soal nomor 6 dengan baik dan benar. Subjek DPS mampu mengerjakan dengan benar dari apa yang diketahui, ditanya, permisalan, model matematika, perhitungan dan kesimpulannya.

\section{Diskusi}

Setelah mendapatkan hasil test yang sudah dijabarkan maka sekarang membahas faktor penyebab kesalahan siswa dalam menyelesaikan soal cerita materi sistem persamaan linear dua variabel ditinjau dari taksonomi SOLO. Ada beberapa faktor kesalahan dari level taksonomi SOLO. Berdasarkan hasil test wawancara dan observasi yang telah dilakukan menunjukkan bahwa kesalahan siswa pada level prastruktural ialah: (1) siswa belum memahami materi sistem linear dua variabel. (2) siswa tidak menuliskan permisalan yang ada pada soal. (3) siswa menulis permisalan tidak sesuai dengan soal. (4) siswa tidak menyelesaikan soal. Hasil penelitian ini sejalan dengan penelitian yang dilakukan oleh Widi Pradini (2019) yang menyimpulkan diantaranya adalah siswa belum menguasai dengan baik materi tersebut, kesalahan karena kecerobohan, lemahnya penguasaan konsep dan belum terbiasanya siswa mengerjakan soal-soal cerita.(Yuliana et al., 2019).

Berdasarkan hasil test wawancara dan observasi yang telah dilakukan menunjukkan bahwa kesalahan siswa pada level unistruktural ialah: (1) salah dalam membuat model matematika. (2) kesalahan dalam perhitungan (3) siswa kurang terliti dalam mengerjakan soal. Hasil penelitian ini sejalan dengan penelitian yang dilakukan oleh Nandya Puspitasari dan Nining Setyaningsih (2016) yang menyimpulkan diantaranya adalah kesalahan konsep dan kesalahan prisip. Meliputi kemampuan siswa yang rendah menafsirkan data, sikap tergesa-gesa siswa dalam mengerjakan soal, lemahnya siswa dalam menerjemahkan soal kedalam model matematika.

Berdasarkan hasil test wawancara dan observasi yang telah dilakukan menunjukkan bahwa kesalahan siswa pada level multistruktural ialah: (1) kesalahan dalam menghitung. (2) siswa tidak mampu menjawab atau tidak mampu menghitung persamaan yang telah diperoleh. (3) kurang baik dalam manajemen waktu. Hasil penelitian ini sejalan dengan penelitian yang dilakukan oleh Yusti Ratna Sari (2019) yang menyimpulkanbahwa hambatan siswa dalam menyelesaikan soal jika dilihat dari taksonomi SOLO diantaranya kesalahan siswa memahami dan membaca soal, kesalahan dalam operasi hitung aljbar.

Berdasarkan hasil test wawancara dan observasi yang telah dilakukan menunjukkan bahwa kesalahan siswa pada level relasional ialah: (1) tidak memberikan kesimpulan. (2) kurang teliti saat mengerjakan soal. Hasil penelitian ini sejalan dengan penelitian yang dilakukan oleh Achmad Rusdiantoro (2020) yang menyimpulkan dalam penelitian bahwasannya menyelesaikan soal sistem persamaan linear dua variabel siswa menyelesaikan soal dengan prosedur tidak benar, kesalahan menyelesaikan soal induksi matematika dan kesalahan dalam menarik kesimpulan (Rusdiantoro, 2020).

Pada level abstrak diperluas siswa mampu mengerjakan soal dari apa yang diketahui, apa yang ditanyakan, permisalan, pembuatan model matematika, perhitungan sampai penarikan kesimpulan dengan baik dan benar. Setelah melakukan wawancara dengan soal yang serupa jawaban siswa sesuai dan benar. Hasil penelitian ini sejalan dengan penelitian yang dilakukan oleh Rosyida Ekawati, Iwan Junaedi, dan 
Sunyoto Eko Nugroho (2013) yaitu untuk mencapai level tertinggi, siswa perlu memahami masalah, menggunakan informasi yang digunakan untuk menyelesaikan masalah dan tepat dalam melakukan perhitungan.

\section{KESIMPULAN}

Berdasarkan hasil penelitian, dapat disimpulkan bahwa kesalahan siswa dalam menjawab soal berdasarkan taksonomi SOLO adalah sebagai berikut:

1. Kesalahan siswa pada level prastruktural (1) siswa belum memahami materi sistem linear dua variabel. (2) siswa tidak menuliskan permisalan yang ada pada soal. (3) siswa menulis permisalan tidak sesuai dengan soal. (4) siswa tidak menyelesaikan soal.

2. Kesalahan siswa pada level unistruktural (1) salah dalam membuat model matematika. (2) kesalahan dalam perhitungan (3) siswa kurang terliti dalam mengerjakan soal.

3. Kesalahan siswa pada level multistruktural (1) kesalahan dalam menghitung. (2) siswa tidak mampu menjawab atau tidak mampu menghitung persamaan yang telah diperoleh. (3) kurang baik dalam manajemen waktu.

4. Kesalahan siswa pada level relasional (1) tidak memberikan kesimpulan. (2) kurang teliti saat mengerjakan soal

5. Pada level abstrak diperluas siswa dapat menyelesaikan soal dengan baik dan benar tanpa melakukan kesalahan

Berdasarkan penelitian mengenai analisis kesalahan siswa ditinjau dari taksonomi SOLO, maka didapat beberapa saran sebagai berikut: Guru diharapkan menjelaskan langkah-langkah menjawab soal saat memberi contoh soal pada siswa, guru untuk memperkuat pemahaman konsep siswa terhadap materi yang dipelajari. Ketika siswa dihadapkan pada permasalahan matematika kontekstual yang biasanya disajikan dalam bentuk soal cerita, siswa akan gagal menyelesaikan masalah tersebut jika tidak memiliki pemahaman konsep matematika yang baik. Pembiasaan kepada siswa untuk mengerjakan soal-soal pemecahan masalah berupa soal cerita juga perlu ditingkatkan, termasuk keterampilan literasi membaca siswa. Hal tersebut akan sangat membantu siswa untuk mengatasi kesulitan siswa dalam mengerjakan soal-soal cerita matematika. Selain itu, penelitian ini masih memiliki banyak keterbatasan, untuk itu diharapkan agar peneliti lain dapat melakukan penelitian serupa dengan melibatkan subjek penelitian yang lebih beragam serta memilih materimateri matematika lainnya.

\section{REFERENSI}

Arico, V. D., \& Wahyudi. (2021). Pelevelan Kemampuan Pemecahan Masalah Matematis Berdasarkan Taksonomi Solo. Jurnal Ilmu Sosial Dan Pendidikan, 5(1), 418-423.

Farmasi, P. S. (2016). ANalisis Kesalahan Siswa Berdasarkan Tahapan Kastolan Dalam Menyelesaikan Soal Cerita Matematika Materi Lingkaran Kelas VIII SMP Negeri 1 Salatiga. 4(4).

Goleman, D. (2019). Analisis Kesalahan Siswa Dalam Menyelesaikan Soal Aljabar Berdasarkan Langkah 
Analisis Kesalahan Siswa dalam Menyelesaikan Soal Cerita Materi Sistem Persamaan Linear Dua Variabel Ditinjau dari Taksonomi Solo pada Siswa, Seila Azmia, Slamet Soro

Taksonomi SOLO. Journal of Chemical Information and Modeling, 53(9), 12-36.

Hardina, S. P., \& Jamaan, E. Z. (2018). Analisi Kemampuan Pemecahan Masalah Matematis Peserta Didik Berdasarkan Taksonomi Solo pada Kelas VIII SMPN 1 Padang. 7(3), 101-107.

Ilmiyah, L., Purnama, S., \& Mayangsari, S. N. (2018). Analisis Kesalahan Peserta Didik Dalam Menyelesaikan Soal Cerita Sistem Persamaan Linear Dua Variabel. AULADUNA: Jurnal Pendidikan Dasar Islam, 5(1), 105-115. https://doi.org/10.24252/auladuna.v5i1a9.2018

Islamiyah, A. C., Prayitno, S., \& Amrullah, A. (2018). Analisis Kesalahan Siswa SMP pada Penyelesaian Masalah Sistem Persamaan Linear Dua Variabel. Jurnal Didaktik Matematika, 5(1), 66-76. https://doi.org/10.24815/jdm.v5i1.10035

Mudhiah, S., \& Shodikin, A. (2019). Pengaruh Model Pembelajaran Berbasis Masalah Terhadap Kemampuan Pemahaman Konsep dan Penalaran Geometris Siswa. Jurnal Elemen, 5(1), 43. https://doi.org/10.29408/jel.v5i1.974

Rosanggren, B. Y., Sugiarti, T., \& Yudianto, E. (2018). Analisis Kesalahan Siswa Dalam Menyelesaikan Soal Cerita Ditinjau Dari Gaya Belajar Kinestetik. Jurnal Pendidikan Matematika, 9, 9. https://jurnal.unej.ac.id/index.php/kadikma/article/view/8024/5658

Rusdiantoro, A. (2020). Identifikasi Kesalahan Peserta Didik dalam Menyelesaikan Soal Induksi Matematika Dengan Teknik Analisis Miles dan Hubberman. 5(2), 1-8.

Yuliana, C., Sanusi, \& Maharani, S. (2019). Analisis Kesalahan Siswa dalam Menyelesaikan Soal Cerita pada Materi Sistem Persamaan Linear Dua Variabel Berdasarkan Kemampuan Siswa. Educatif: Journal of Education Research, 1(1), 17-26. https://doi.org/10.36653/educatif.v1i1.3 